\title{
On the structure of business incubators: de-coupling issues and the mis-alignment of managerial incentives
}

\author{
Ali J. Ahmad ${ }^{1}$ Courtney Thornberry ${ }^{2}$
}

Published online: 31 December 2016

(C) The Author(s) 2016. This article is published with open access at Springerlink.com

\begin{abstract}
Business incubators are structurally complex and have resisted any major change to their internal structure, replicating throughout the world in large numbers, and delivering value through numerous models. A question, thus arises, what specific structural properties of incubators facilitate the organizational form's replication and performance in a range of institutional contexts? In order to shed light on this question, an exploratoryinductive approach is adopted; and, utilizing the tools of organization theory, the internal environment of the business incubator is de-coded. This draws attention to attributes of the hybrid incubator-form's internal structural properties that have not been discussed in the past, including de-coupling issues and the mis-alignment of managerial incentives with the actual role of incubating. These properties, rather than impacting incubators' status, award incubators with ceremonial value and help their managements avoid close inspections of performance. This in turn, it is proposed, has allowed for their rapid replication in a variety of socio- cultural, economic and institutional contexts.
\end{abstract}

Keywords Hybrid organizations · Business incubator · Institutional theory · Organizational theory

Ali J. Ahmad

ali.ahmad@warwick.ac.uk

Courtney Thornberry

c.thornberry@warwick.ac.uk

1 Warwick Manufacturing Group, International Digital Laboratory, University of Warwick, Coventry CV4 7AL, UK

2 Warwick Manufacturing Group, University of Warwick, Coventry CV4 7AL, UK 


\section{Introduction}

Business and technology incubators became popular in the United States in the 1980s and have since spread throughout the world as a means of supporting the development and growth of start-up companies and facilitating the commercialization of scientific and technological innovations (Mas-Verdu et al. 2015; Sá and Lee 2012). Sometimes known by other names, such as research parks or innovation centres (Aernoudt 2004), they operate by providing entrepreneurs with an array of targeted resources and services such as low-cost space, shared equipment and services, and a range of administrative, consulting and networking. Their main objective is to produce successful firms that will leave the programme financially viable and freestanding (Bollingtoft and Ulhoi 2012; Grimaldi and Grandi 2005; Hackett and Dilts 2004a).

Faith in incubators is most likely based on evidence which suggests that the model is capable of establishing SMEs at a faster rate and at a lower cost than other policy instruments (Costa-David et al. 2002). This role is evidenced by the growing number of incubators worldwide with positive testimonials (Khalid et al. 2014; Sanders 2014). Business incubators-incubation is utilized by a wide range of actors (e.g., public sector science and technology laboratories, academic institutions, development authorities and corporations) in an array of traditional [example: for-profit, not-for-profit, hybrid (Allen and McCluskey 1990) and campus (Mian 1997)] and new [example: virtual (Nowak and Grantham 2000); specialist (Schwartz and Hornych 2008), and the 'business accelerator' (Cohen 2013)] models for purposes ranging from economic development to promotion of technology entrepreneurship and innovation (Bruneel et al. 2012).

The above cited incubator models demonstrate interesting differences even though their ultimate objective (irrespective of the delivery mechanism) may be the same- "to support the creation and growth of its client firms during the start-up years through value-added contributions-the incubation process" (Mian 1997, p. 257). From an internal structure standpoint, inter-model differences may emanate due to differences in the combinations, mechanisms, intensity and proportions of services offered by different types of incubator organizations (Clarysse et al. 2005). However, given their purpose-an organization designed to grow other organizations-incubators have demonstrated significant structural robustness, resisting any major change to form in nearly four decades. In essence, following the original ethos instituted by incubator pioneers such as the Mancuso brothers (Adkins 2002). This observation has resonated with researchers in the area who have acknowledged incubator-incubation's ability to consistently deliver benefits through a wide variety of models in a range of socio, cultural, economic and institutional contexts (Khalid et al. 2014; Sanders 2014; Bruneel et al. 2012; Aaboen 2009; Phan et al. 2005; Bergek and Norrman 2008; Aernoudt 2004; Hackett and Dilts 2004a, b; Lewis 2002). The question arising therefore is: what are incubators' unique structural properties that have allowed this organizational form to replicate around the world, and to deliver benefits in a variety of geographical contexts?

Answering the above question is fraught with difficulty due to limitations of extant frameworks in organization theory. Hackett and Dilts (2004b) and Ahmad (2014) have reviewed the usefulness of a wide range of theoretical frameworks to explain the existence and internal mechanisms of incubators, settling on the Real Options Theory and Social Mechanisms Theory, respectively. While valuable contributions have been made around how incubators function, unfortunately, our understanding around the reasons why incubators are rapidly growing in numbers around the world and have been able to consistently 
deliver value, despite academic criticisms (see for instance Sherman 1999; Rudy 2004; Sofouli and Vonortas 2007; Tamásy 2007) remains rudimentary.

In order to advance understanding in the above area, it is proposed that the knowledge deficit on incubators' structural properties which allow replication and efficient functionality irrespective of context, may be remedied by utilizing the theoretical lens of hybrid organizations. It is argued that incubators neatly fall into the category of hybrid organizations such as associations, educational organizations, collaborative outsourcing, franchising, cooperatives, partnerships, business groups, subcontracting, and co-opetition on which useful theoretical advances have been made (Jolink and Niesten 2012; Borys and Jemison 1989). Research in the area of hybrid organizations falls within the wider body of knowledge often referred to as 'organization theory', and focuses on the formation, functioning and implications of hybrids. Thus, advances in the area of hybrids are likely to benefit in the development of explanatory theory in the area of incubators-incubation as well. Following on from this proposition, the aim in this paper is to contribute new explanatory theory which draws attention to incubators' structural properties, which facilitate its replication and performance in a range of contexts. The paper's major contribution comes from case study-based research conducted at two incubators in Dublin, Ireland. Results are grounded in concepts from hybrid theory which explain aspects of incubators' structure.

The paper is organized as follows: in the next review section work on hybrid organizations and structural properties of incubators is surveyed with the presentation of key highlights and gaps in understanding. Next, this research's methodology is presented, which includes a clarification of its theoretical lens, and details on data collection and analysis methods. In the following analysis section, two themes are drawn from the analysis work and are elaborated upon using data and previous literature. In the discussion section, the key outcomes and contributions of the research are highlighted and finally, in the conclusion section, the research's limitations are acknowledged and recommendations for further inquiry are made.

\section{Literature review}

\subsection{Hybrid organizations}

The rapid and unpredictable change in the environment of organizations (Hoffmann 2007) in the last decades has led to a substantial increase in the number of inter-organizational collaborations, leading to the formation of hybrids (Bercovitz and Feldman 2007; Capaldo and Petruzzelli 2011). Jolink and Niesten (2012) have proposed a definition of hybrids which explains their formation, functioning and implications. Their definition is based on key insights gained from recent literature on hybrids that used a variety of theoretical perspectives in combination with agency and property rights theory, transaction cost economics (TCE) and the resource-based view. They suggest that organizations become hybrids to create value and to more efficiently share resources, where it would be important to consider a combination of all the issues that are raised by each of the above theories separately. Decisions must be taken on the best means to achieve efficient collaboration and coordination; this would involve safeguarding against contractual hazards to a reduction of transaction costs, the organizing of information in a way so as to reduce agency costs, and entering into re-contracting to allocate residual claims. Thus, they define 
hybrids as: "collaborations between independent organizations that exchange and co-develop goods and services to create value, reduce agency and transaction costs and allocate residual claims, by combining resources, organizing information, and safeguarding contractual hazards and property rights" (Jolink and Niesten 2012, p. 4). This definition applies well to business incubators as they have been viewed as hybrid networked organizational forms, emerging as a result of territorial synergy, physical proximity, relational symbiosis, and economies of scale (Bollingtoft and Ulhoi 2005).

Battilana et al. (2015) extend the above definition and propose that hybrids are: "those enterprises that design their business models based on the alleviation of a particular social or environmental issue". They clarify that income and capital are generated from either for-profit models, non-profit models or a mixture of both. This definition would suggest that the hybrid nature of the business was also motivated by ethical issues, as well as the useful aspect of resource-sharing. Once again, this definition too applies to incubators; incubator-incubation researchers have long stressed that the primary motivation behind not-for-profit incubators, which is the predominant model for incubators, has been on job creation and the upliftment of local communities through the promotion of entrepreneurial risk taking (Hongyi et al. 2007; Hughes et al. 2007; Cooper and Park 2008; Ndabeni 2008).

The literature on hybrids which utilized organization theory has contributed a number of useful insights and offers explanations for the formation, functioning and implications of hybrids based on distinct sets of theoretical characteristics (Jolink and Niesten 2012). Such explanations include why firms engage in this (hybrid) type of organizational form (formation), the different kinds of mechanisms that maintain the hybrid form of organization (functioning), and the impact or performance of the organizational form (implications). The theoretical lenses that researchers have favoured to explain the formation-functioningimplications of hybrids have been largely similar to those used for traditional organizations, and include agency theory, property rights theory, transaction cost economics (TCE) and the resource-based view (Barney and Hesterly 2006).

First, studies demonstrate that rules and regulations in the institutional environment influence the formation of hybrids (Barretta 2008). Second, the environment has a direct impact on the functioning of hybrid organizations, and that hybrids serve as safeguards for transactions where the institutional environment does not perform this function (Ménard 2010; Lyon 2006; Yvrande-Billon and Ménard 2005). Third, institutional environments also enable hybrids to create value, but also have the potential of creating performance problems (Raynaud et al. 2009; Ulset 2008). Fourth, the alignment of governance with technology and strategy are important for the functioning of hybrids (Raynaud et al. 2009). Fifth, the network perspective suggests that hybrids endeavour to become the focal firm in a network in order to increase its value and to attract future alliance partners. Firms in a network with a high degree of resource interdependence are likely to collaborate to form hybrids (Ozcan and Eisenhardt 2009). Sixth, the literature on trust emphasizes that preexisting trust relations in a network determine the formation of new alliances. Woolthuis et al. (2005) suggest that trust is the intentions of a firm's partner towards their relationship, particularly in refraining from opportunism. They report that when there is no fear of opportunism, contracts do not include clauses on the protection of property rights. Conversely, when there is a high chance of opportunism, safeguards on property rights are included in the alliance contract. The functioning of hybrids is dependent on trust to ensure the disclosure of knowledge by the other contracting party, or to continue and renew the relationship (Woolthuis et al. 2005).

When it comes to incubators, and specifically to the aim of this research which deals with their internal structural properties, it is proposed that the above perspectives which 
highlight the importance of strategic alignment between governance and technology (which could also be non-technical rules and procedures on how to get work done) and trust are most helpful.

The next section will consider what is known about the structures of business incubators and establish the research gap when conceptualising business incubators as a form of hybrid organization.

\subsection{Structural properties of business incubators}

A recent content analysis and review on business incubator literature published from 1985 to 2012 indicated a vast majority of publications (56\%) focus on the creation and effects of business incubators in an entrepreneurial environment (Perdomo et al. 2014). Due to the varied nature of research in this area, the authors stressed the need for an improved structure of further research on business internal structures. Structure here is viewed as the "established pattern of relationships among the parts of the organization" (French et al. 1985, p. 348). Exploration into current business incubator research shows no explicit work with regards to the actual organizational structure of organization. A few publications focus on the specifics of main attributes and classifications of business incubators, namely; services and strategies, knowledge structure, networking and cooperation (Perdomo et al. 2014) and the role of the incubator management/manager (Ahmad and Ingle 2011; Ahmad 2014). These attributes can be considered as contributing factors to the overall structure of a business incubator, and contributions by incubator-incubation scholars in these three areas are reviewed below.

\subsubsection{Services and strategies}

Bergek and Norrman (2008) identified three main types of services that tenants can access from a business incubator; (1) infrastructure, which is use of physical facilities such as buildings and equipment; (2) business support; that is consulting and expert advice from incubator employees and (3) mediation; that is a network with potential partners and collaborators outside the incubator. Robinson and Stubberud (2014) investigated the use of these services and found that the sharing of knowledge was more common than sharing or using facilities. They suggested that, in some instances, educational or mentoring programs may be more cost effective than incubators. They acknowledged, however, that incubators are still young and much more research needs to be conducted to truly understand their value. Vanderstraeten and Matthyssens (2012) considered the strategies that needed to be applied to help differentiate incubators to their tenants. Two interesting findings from their research include (1) diversified incubators may lead to more success than specialized ones and (2) the aspect of co-creating of value with the tenant is key to success. This ability to create value is supported by the knowledge structure of the incubator.

\subsubsection{Knowledge structure}

A core competency of a business incubator is the knowledge it is able to share with tenants. It is also a core structure of a business incubator and critical to consider to understand the overall structure of the organization. Aaboen (2009) argues that there are two main types of knowledge, technical and client. Client knowledge can encompass the specific details 
known about the tenant, as well as the relevant market and business knowledge needed to achieve success. Rubin et al. (2015) follow a similar theme, though instead presenting three types of knowledge from their research; technological, market and financial. This further categorizes client knowledge into understanding of the market and knowledge of business and financial structures. Knowledge was found to be the essential attribute of networks in a study conducted by Zhang et al. (2016), as they found that specific knowledge structures of an incubator, that is channels through which knowledge is shared and used, affects innovation activities. This contributes directly to both networking and cooperation activities that take place in incubators.

\subsubsection{Networking and cooperation}

Networking impacts the success of cooperative activities in business incubators. Schwartz and Hornych (2010) investigated the cooperative patterns of 150 German incubators to better understand how networking contributed. They found no great different between two main types of incubators, those that specialize in a particular market or industry, and those that are more diversified in their skill set. Additionally, they found that informal networking was the strongest attribute that led to successful cooperative activities, which was established through a strong feeling of trust and promoted by incubator management. Scillitoe and Chakrabarti (2010) also considered networking in their study of American and Finnish incubators. Counselling and networking were differentiated in their work; they found that networking helped ventures with technological-know skills whereas counselling, mainly from incubator management, assisted more with business understanding.

A particular point of interest within the literature about networking and cooperation is the focus on incubator management and the role it plays in the success of the incubator overall (Schwartz and Hornych 2010; Scillitoe and Chakrabarti 2010).

\subsubsection{The incubator management/manager}

Incubator management (IM) as a role is not as well defined when compared to roles in other professions such as Chartered Accounting, Actuarial Science or Law. In the absence of a recognized academic or industrial qualification for incubator managers, incubator professionals often rely on imagination, previous business experience and by learning on the job (SUMMIT-II 2010). Practitioner literature time and again emphasizes that the success of an incubator is heavily dependent on the person appointment as the Manager. The NBIA recommends, for instance, three principal qualities of an IM: (1) must be a good 'people manager' since the IM simultaneously needs to manage the Incubator Board, stakeholders, staff and clients; (2) should have entrepreneurial experience, having succeeded or failed in starting his/her own business (preferably in the targeted industries) so that client firms can relate to and respect the individual; and (3) must be a good communicator since a really critical task for the IM is to promote the incubation programme in all kinds of business settings and to market it to different stakeholders, including the client firms (Boyd 2006).

Although there is no accepted code defining the precise role and accompanying tasks of an incubator manager, practitioner literature suggests the importance of leadership qualities (UKBI 2001; Byrne 2005; NBIA 2008). The effectiveness of leadership styles has long been a topic of discussion in both academic and practitioner circles (Howell and Avolio 1992; Avolio and Bass 1995; Avolio 1999). A majority of managers exhibit components of several different leadership styles such as transformational behavior, contingent reward 
leadership and management-by-exception leadership (Bass and Steidlmeier 1999), therefore, it becomes difficult to precisely point-point an individual manager's exhibited style. However, researchers agree that effective leadership in any role requires a manager to be adept at a number of common skills such as being able to develop and coach subordinates, communicate clearly, resolve conflicts, analyze problems, make sound decisions, be able to respond to work challenges in a positive way, use time efficiently, and delegate work (Davis et al. 1996).

The incubator managers must demonstrate the above qualities as part of their work at the incubator, helping nascent entrepreneurs identify opportunities and take reasonable risks to grow their enterprises (Todorovic and Moenter 2010).

\subsection{Concluding remarks}

Considering the definitions of hybrid organizations has helped to clarify their connection with business incubators. Business incubators, like all hybrid organizations create value through resource sharing, achieved from efficient collaboration and coordination; especially through the networks they are able to establish for their tenants and from the internal and external knowledge they access. Although we have descriptive information through the efforts of previous researchers on incubators' services and strategies, knowledge structure, networking and cooperation and the role of the incubator management/manager; what is presently unclear is the nature of work inside the incubator organization, and the manner in which the incubator creates value and is able to maintain its internal organizational form through (1) integration (the way activities are coordinated), (2) differentiation (the way tasks are divided), (3) the structure of the hierarchical relationships (authority systems), and (4) the formalised policies, procedures, and controls that guide the organization (administrative systems). It is proposed that focusing on the above themes will help in shedding light on a number of interesting structural properties of incubators including decoupling and mis-alignment of managerial incentives-aspects which introduce uncertainty, information asymmetry and contracting complexities.

\section{Methodology}

The primary aim in the empirical component of this research is to highlight aspects of incubators' internal structure and environment that contribute to the formation of a hybrid form of organizational coordination and control. This will help in explaining how incubators have been able to not only maintain the internal structure, but also effectively replicate it in various geographical environments, which would also imply institutional contexts. Given the research's raison d'être, the case study provides the necessary methodological framework for a reliable and in-depth investigation of incubators' internal environment. The case study is a methodologically flexible approach to research design that focuses on a particular case-whether an individual, a collective or a phenomenon of interest. It is known as the 'study of the particular' for its thorough investigation of particular, real-life situations (Rosenberg and Yates 2007). Thus, the methodology fits in well with the research's Interpretivist worldview.

The "instrumental case study" was most suitable considering the objective and requirements of this research. Here the case itself is secondary to understanding a particular phenomenon, therefore, the focus will remain on the 'internal structure' rather than a 
particular 'incubator organization' enacting that process. It offers thick descriptions of a particular site, individual or group (multi-unit analysis).

\subsection{Case selection approach and criteria}

The case study was deliberately constructed so as to maximize the opportunities for learning through cross-case comparison. The approach of using multiple cases for comparative analysis has a number of advantages over single case studies. For instance, only a comparative approach can help in identifying client selection approaches that maybe specific to particular types of incubator organizations. Comparative analyses allow for prescriptive learning, such as looking at what management techniques or approaches can be transferred across models. Finally, comparative studies bring more rigor to research allowing the testing of generalizations such as dominant management models and techniques.

According to Yin (2009), when using multiple cases, case selection must lead to either (a) the prediction of similar results (a literal replication); or (b) the development of contrasting results but for predictable reasons (a theoretical replication). In this research, the aim of the multiple case selection strategy was to compare and contrast results or theoretical replication.

The problem of generalization associated with qualitative case study research has been due to the simplified understanding of the concept where it is generally assumed that a sample of cases has been drawn from a larger universe of cases. Thus, the incorrect terminology "small sample" arises, as though a single-case study were a single respondent. Yin (2009) argues that the confusion arises when one is unable to differentiate between 'analytic generalization' and 'statistical generalization'. Yin refuted this criticism by clearly differentiating analytic generalization from statistical. In statistical generalization, an inference is made about a population (or universe) on the basis of empirical data collected about a sample (such as via surveys). In analytical generalization, previously developed theory is used as a template against which to compare the empirical results of the case study, in other words, the investigator is striving to generalize a particular set of results to some broader theory (Yin 2009).

It was believed that for the twin case strategies of analytic generalization and theoretical replication, results from two cases sufficed. Collection of data from the participants in the case organizations continued until data saturation points were reached (i.e. no new information came forth). The chosen case organizations are discussed in the following section.

\subsection{About the case organizations}

The research took place in Dublin-Ireland. The Republic of Ireland began investing much later in incubators when compared to other EU nations. At the time of data collection (2010-2011), Ireland was investing heavily in setting up business incubators, the policy environment favoured the setup of incubation facilities at all tertiary educational institutions (universities and polytechs) in the Country as a matter of priority. Thus, the enthusiasm around incubators-incubation was quite high, incubator managers and client firms were willing to engage with researchers and to share insights, and new models and best practices were being experimented with. These conditions presented a viable research incentive; an opportunity to examine an interesting and developing phenomenon where the likelihood of finding novel outcomes was higher in comparison 
to other developed tier 1 EU nation states whose incubation systems were older and more mature.

According to the 2014 report on Entrepreneurship in Ireland prepared by the Government (Entrepreneurship in Ireland 2014), there are two different types of incubators in the Country providing start-up support. These include:

1. University Campus Incubators These are incubators linked to either 3rd level institutes of higher education or the various institutes of technologies (ITs) in Ireland. The idea behind the establishment of these entities was to support academic researchers to take the outputs of research with commercial potential and bring it to a point where it can be transferred into industry or be commercialized. The client-mix at these facilities is, therefore, inclined towards the sciences or engineering. The incubators are usually set up as independent entities with a $\%$ of shareholding (in terms of equity input) of both university-IT (where equity contributed is usually land/space) and EI. There are 30 such facilities across the country, of which 5 specialize in bio-technology (EnterpriseIreland 2015).

2. Community Enterprise Centres These are rooted in the local community, and their objective is generally to provide local employment through the generation and support of local enterprise. They have, in most part, been established by local communities on a mostly self-help basis with support, at times, from local County Enterprise Boards. These facilities are mixed-use incubators catering to wide array of small business sectors and are not usually purpose built. They provide office space, commercial kitchen space, work shop space alongside advice, training, mentoring and other support services such as reception desk, conferencing, mail handling, shared internet, cafeteria and so on. There are 120 such facilities (NACEC 2015).

Two of the largest and oldest incubators from the above categories were selected for this research. DubInc - a mixed-use business incubator (a community enterprise centre) representing the traditional model of business incubation and IncuWorks-a universitycampus based hi-tech incubator.

\subsubsection{DubInc}

DubInc was established in the mid-1980s as a result of a decision at a large public meeting organized by a local community in Dublin. The community met to decide on options to remedy the significant problem unemployment in the area. The answer at the time was proposed by a visiting foreign consultant and backed by a number of public-spirited local businessmen. The idea came from the US, where local volunteers offered their expertise to unemployed people, helping them become entrepreneurs. The suggested vehicle was an 'Enterprise Centre' would be set up to supply offices, work space and communal secretarial services. It was agreed that the initiative's key objective would be 'job creation' and 'community revitalization'.

The Centre had eight staff members who provided advisory and administrative support to client businesses. The services offered by DubInc can be categorized in a number of ways: according to their various types of clients; the type of service itself (such as infrastructural or advice-based or a combination); whether they were free or charged; whether they were exclusive to a particular category or available across the board and so on. These included: 
1. One-to-One Business Advice and Guidance

2. Assistance with business planning

3. Assistance with funding applications

4. Business network meetings

The two significant revenue streams for the Centre were rentals paid by incubation clients and the array of training courses offered. A diverse mix of clients was based at DubInc with a range of backgrounds, industry exposure, experience and business models, belonging to industries such as power/energy, information technology, publishing, insurance, optics, food and construction.

\subsubsection{IncuWorks}

IncuWorks was based at a prominent Dublin university. Its Board had been mandated to function under the broad strategic outlook of the hosting university's innovation strategy. The physical facility was located within the University confines in an up-market area of Dublin city with close proximity to the city centre, bookshops, banks, restaurants, sports and other facilities. Since its inception, IncuWorks had been recognized both locally and internationally through a number of awards as a high quality and effective organization.

Staff complement was approximately 15 professionals responsible for overall leadership, operations, enterprise development, technology transfer and intellectual property protection, communication, continuing professional development, facilities management and administration. Supporting the Enterprise Development function was an outside network of experts and specialist firms.

IncuWorks offered a range of services in its areas of operation. An exhaustive listing of services will not be instructive since they were flexible and tailored to suit the needs of a particular client. Its revenue came from only one major source: client rentals. IncuWorks attracted clients in the hi-tech sector and its support programmes were designed for their requirements. Rental pricing was competitive and based at par or slightly below existing commercial letting rates in its vicinity.

\subsection{Data collection and analysis}

The tables below present details on the interview subjects at DubInc and IncuWorks respectively. A client numbering system was developed which places DubInc clients in the range of 1-20 and IncuWorks clients in the range of 21-39. This allows the tracing of specific quotes used in the analysis back to particular respondents (Tables 1,2).

Data was collected over a period of approximately 6 months at each case organization during weekly visits. A research plan was drawn up in coordination with the incubator manager (IM), the point of contact, which contained scheduling details on a series of semistructured, face-to-face interviews with both clients (business founders) and members of the incubator organization. The purpose of these interviews was to obtain an understanding of participants' perception of the incubation process, how it unfolded for their firm and the internal normative environment of the incubator. With support from the IM, emails were sent to clients to confirm the schedule. In addition to interviews, the research plan included the attendance of the researcher at a number of up-coming 'incubation' events taking place in the incubator.

A total of 68 interviews (11 with members of incubator managements and 57 with clients) were conducted, recorded and transcribed, each lasting 35-45 min. An interview 
Table 1 DubInc interview subjects

\begin{tabular}{|c|c|c|c|c|}
\hline \multirow[t]{2}{*}{ Incubator management } & \multicolumn{4}{|c|}{$\begin{array}{l}\text { 1. Enterprise Manager } \\
\text { 2. Previous Enterprise Manager } \\
\text { 3. A member of the Board of Directors } \\
\text { 4. Enterprise Officer } \\
\text { 5. Facilities Assistant } \\
\text { 6. Receptionist Support Staff }\end{array}$} \\
\hline & Industry & Nature & Team size & Stage \\
\hline Client 1 & Energy/power & Design & $>5$ & Year 3 \\
\hline Client 2 & Energy/power & Equipment manufacture & $>5$ & Year 3 \\
\hline Client 3 & Energy/petroleum & Project management & 4 & Year 4 \\
\hline Client 4 & General & Social entrepreneur & 3 & Year 3 \\
\hline Client 5 & General & Medical diagnostics & 2 & Year 1 \\
\hline Client 6 & General & Bespoke stitching & 4 & Year 1 \\
\hline Client 7 & General & Health/therapy & 1 & Year 4 \\
\hline Client 8 & General & Consulting and training & 4 & Year 4 \\
\hline Client 9 & Food & Web portal & 1 & Year 3 \\
\hline Client 10 & Food & Processing and sales & 1 & Year 2 \\
\hline Client 11 & Food & Processing and sales & 1 & Year 1 \\
\hline Client 12 & Food & Processing and sales & 1 & Year 1 \\
\hline Client 13 & Construction & Recruitment & 1 & Year 2 \\
\hline Client 14 & Insurance/energy & Consulting & 2 & Year 2 \\
\hline Client 15 & Software & Sales & 1 & Year 3 \\
\hline Client 16 & Hi-tech/knowledge & Consulting & 3 & Year 1 \\
\hline Client 17 & Publishing & Design/printing & 2 & Year 4 \\
\hline Client 18 & Property & Management & 2 & Year 3 \\
\hline Client 19 & Optical & Web sales & 2 & Year 1 \\
\hline Client 20 & Optical & Testing/sales & 4 & Year 4 \\
\hline Ex-Client & ICT & Internet and web dev. & 5 & - \\
\hline
\end{tabular}

guide' was prepared using previous literature and keeping in mind the major aim of the research. The approach to interviewing was semi-structured and was informed by Patton (1990). In addition to semi-structured formally arranged interviews, more informal exchanges during numerous chance encounters with clients also occurred, for instance, at the incubator's cafeteria or at the reception desk. Any notable points arising out of these discussions were duly recorded in a field diary. This diary was also used to record observations and to chronicle thoughts, feelings, experiences and perceptions of the researchers throughout the research process. In addition, a field log was also utilized providing a detailed account of the various ways in which time was spent when on-site. During each visit, in addition to the scheduled face-to-face interviews with clients and other members of the incubator organization, there was a 30 min meeting with the IM also arranged. The purpose was to factor-in perceptions from both IMs and clients which allowed the researchers to juxtapose data and draw more nuanced conclusions.

Eisenhardt and Graebner (2007) suggest that theory building from qualitative research is an inductive process. The focus was to extract meaning in complex qualitative data through 
Table 2 IncuWorks interview subjects

\begin{tabular}{|c|c|c|c|c|c|}
\hline \multirow[t]{2}{*}{$\begin{array}{l}\text { Incubator } \\
\text { management }\end{array}$} & \multicolumn{5}{|c|}{$\begin{array}{l}\text { 1. Director } \\
\text { 2. Manager Enterprise Development } \\
\text { 3. Manager Communications } \\
\text { 4. Manager Technology Transfer } \\
\text { 5. Facilities Manager }\end{array}$} \\
\hline & Industry & Nature & Route & Occupancy & Stage \\
\hline Client 21 & ICT & $\begin{array}{l}\text { Consulting, design, } \\
\text { testing }\end{array}$ & Spin-in & Incubation & Year 2 \\
\hline Client 22 & ICT & Product design & CCDP & $\begin{array}{l}\text { Desk } \\
\text { Space }\end{array}$ & Year 1 \\
\hline Client 23 & ICT & $\mathrm{R} \& \mathrm{D}$ & $\begin{array}{l}\text { Spin- } \\
\text { out }\end{array}$ & Associate & Extended \\
\hline Client 24 & ICT & Internet technologies & Spin-in & Incubation & Year 3 \\
\hline Client 25 & ICT & Internet technologies & CCDP & Incubation & Year 1 \\
\hline Client 26 & ICT & Internet technologies & Spin-in & Associate & Year 3 \\
\hline Client 27 & ICT & Misc. & Spin-in & Desk space & Year 1 \\
\hline Client 28 & ICT & Software development & Spin-in & Desk space & Year 1 \\
\hline Client 29 & ICT & Internet technologies & CCDP & Associate & Year 1 \\
\hline Client 30 & ICT & Internet technologies & Spin-in & Incubation & Year 2 \\
\hline Client 31 & Telecom & IP commercialisation & Spin-in & Incubation & Year 1 \\
\hline Client 32 & $\begin{array}{l}\text { General/Hi- } \\
\text { tech }\end{array}$ & Consulting & Spin-in & Desk space & Year 1 \\
\hline Client 33 & $\begin{array}{l}\text { General/Hi- } \\
\text { tech }\end{array}$ & Consulting & Spin-in & Incubation & Year 1 \\
\hline Client 34 & Bio-tech & Fuel & Spin-in & Incubation & Year 2 \\
\hline Client 35 & Bio-tech & Engineering R\&D & $\begin{array}{r}\text { Spin- } \\
\text { out }\end{array}$ & Incubation & Year 3 \\
\hline Client 36 & Bio-tech & $\begin{array}{l}\text { Clinical trials, drug } \\
\text { testing }\end{array}$ & $\begin{array}{l}\text { Spin- } \\
\text { out }\end{array}$ & Incubation & Year 3 \\
\hline Client 37 & Bio-tech & $\begin{array}{l}\text { Drug Testing/ } \\
\text { development }\end{array}$ & CCDP & Associate & Year 1 \\
\hline Client 38 & Bio-tech & R\&D & $\begin{array}{l}\text { Spin- } \\
\text { out }\end{array}$ & Incubation & Year 2 \\
\hline Client 39 & Bio-tech & Clinical R\&D & Spin-in & - & Graduated \\
\hline
\end{tabular}

the development of summary themes or categories from raw data through a process of data reduction. In order to induct meaning from case data, the qualitative data analysis rules recommended by Miles and Huberman (1984) were followed. These authors point out that careful descriptions of events, people and settings is one of the most important contributions of qualitative research. This requires an interpretive and analytic effort to illuminate the constant, influential and determining events which shape the course of events. Hence, qualitative data analysis would be a formalized yet creative process (Miles and Huberman 1984). 


\section{Analysis of findings}

\subsection{Nature of work}

The Incubator Manager's (IM) role as a manager and leader is multi-faceted and complex. When analyzing the IM's nature of work, two distinct areas of intervention become apparent; (a) the role as manager-leader of the incubator staff and organization (corporate and physical); and (b) the role as a mentor-coach to incubation clients. The responsibility, accountability, incentives and rewards associated with these two areas are different, and the IM is usually on a tightrope in order to ensure that the allocation of energy and time to corporate versus incubation activities is in accordance with the expectations set out by the incubator's Board of Directors. For the IM, like any top-tier manager, meeting the Board's expectations and achieving set targets is linked to compensation and promotion. Therefore, IM time allocation should be impacted by the way in which Board strategic targets are tied in with IM incentives.

The Board, however, are only able to effectively govern (and as a consequence evaluate) the IM's corporate role, since associated outputs are usually in the form of tangible numeric indicators, such as $\%$ growth in revenue or implementation of a certain infrastructural upgrade scheme. Evaluating the IM's incubation-related role is much more difficult to evaluate due to the problem associated with identifying and putting a measure on intangible indicators. For instance, the DubInc IM stated:

[DubInc IM] ...Putting a dollar value on our work is unrealistic...I mean...how will the allocation of three hours of joint-planning time with an IT client be weighed in comparison to one hour of commenting on a food sector client's business plan?... [IncuWorks IM] ...My work with clients is quite difficult to precisely document...a lot happens during a typical day, week and month...from a conversation in the cafeteria, to an email exchange...it would take a lot of my time capturing all these interventions...it would not be practical...

A significant part of the IMs' work related to building a community orientated ethos within the incubator and to project such an image to outside stakeholders, the wider community and potential new clients. Further, both IMs believed that the most complex part of their work was building trust with clients, where there was need for them to be viewed as not only subject experts who were technically competent but also as individuals who were genuinely interested in clients' welfare:

[DubInc IM] ...It is essential that we are seen as a community orientated organization, everything we do here is about ensuring that our reputation for promoting new start-ups and employment opportunities is maintained...over the past two decades or so we have built the local community's confidence, and when people apply here for space, it is on this very basis...

[IncuWorks IM] ...We have had a number of positive evaluation results which we publicize widely...but to be honest to succeed as an incubator means to succeed in building clients' trust...business start-up is a difficult process, entrepreneurs can be difficult individuals, sharing internal details about IP and future plans openly requires that we build in clients a degree of confidence...this is a very subtle skill...

It was found that much of the value that clients derived from incubation had little to do with the efficiency of developmental activities. Measuring what clients learn and the 
impact of that learning on economic growth targets and what IMs are actually delivering/contributing introduces unnecessary uncertainty, and creates doubts about the effectiveness of the status structure of the incubator organization. Even if indicators and measures were developed, due to the randomness and complexity inherent in incubation, capturing and logging precise details (for later appraisal) is likely to lead to a high cost administrative overload. By minimizing resources devoted to coordination and control, the incubator furthers its ability to increase the ceremonial worth of its contribution to client firm development and "success".

Amongst the most important indicators by which IM performance was judged at DubInc (in the absence of external assured income), was ensuring that the organization generates enough revenue on a month-to-month basis to meet its short and long term financial commitments. Assuring performance on this key indicator meant that the IM's energy and time was diverted to a variety of corporate revenue generating activities such as funding and developing community schemes, marketing training programmes and running short courses. The IM's compensation and benefits were linked to the liquidity situation of DubInc and not strictly to how well client firms were performing (which ought to be, by some standards, the real IM performance indicator). Interestingly, the DubInc IM, realized that the above had the potential to tarnish organizational reputation:

[DubInc IM] “...We do a lot of work with our existing clients and people walking in but there is no way to show the impact of all this effort...we want to start compiling data about our clients and the progress they make...so when we present our case to Enterprise Ireland we will have concrete figures..."

The IM had, therefore, commissioned a software company to implement a tracking and monitoring system to log incubation activity. This system (under design when the research was conducted) was to contain client firm data in the form of profiles created on the day of first contact till the time a client graduated. It is important to note that this new software system was exclusively for incubation and was in no way meant to be connected to the incubator's corporate accounting, payroll, inventory and other systems.

Unlike DubInc, at IncuWorks a number of incubation-focused key performance indicators for the IM did exist. The IM's role (as described) was "tech. transfer from University to spin-outs". Towards the accomplishment of this primary role, a number of key performance indicators (monitored on a yearly basis) were allocated to the IM including: (1) number of new spin-outs created; (2) number of new desk space clients inducted; (3) number of new unit clients inducted; (4) number of feasibility grants acquired from Enterprise Ireland; and (5) seed funding/capital raised by new clients. These indicators are meant to report actual performance not actual performance versus set targets. In other words, at the strategic level, there were apparently no firm targets set out on a yearly basis including how many new spin outs were to be created or how many new unit clients were to be inducted.

According to the IncuWorks' IM, the performance indicators were reviewed annually, however, it was not revealed whether there were any consequences for non-performance. Due to our new understanding of incubators based on the concept of de-coupling, it may be argued that even with the presence of key performance indicators, the IncuWorks' IM's true role remained largely uncontrolled and unmonitored. Consider the efficacy of the indicator- "number of new spin-outs created"; a number, let us assume '3' new spin-outs, what does it really tell us about the precise role and contribution of the IM? Similarly, the number of new desk space and unit clients inducted may or may not have anything to do with the IM's effort. Numerically, how will the IM's contribution by way of a VC 
introduction be delineated from the (hypothetically speaking) $€ 500000$ of seed capital raised by a client? Thus, the indicators are not true measures of IM performance and this fact has also been brought out in practitioner literature and surveys (UKBI 2006).

\subsection{Incubator management and incubation management}

The IM job description breaks down the task of 'incubator management' into two basic categories: (1) corporate activities aimed at running the organization like a business; and (2) activities focused on helping client firms grow. The IMs at the case organizations, when asked what the requirements of the role were, responded as follows:

[DubInc IM] “...My job requires a number of things of me, I am here to progress DubInc's vision and mission of local community development through the promotion of an enterprise culture, I am responsible for the overall management of the facility and for making plans for its expansion and to provide whatever support we can to our clients..."

[IncuWorks IM] “...I will have to say that tech-transfer from the University (hosting institution) to the market is my key role. This requires the identification of intellectual property, working with our scientists and researchers to develop commercial proposals and business plans and then help in raising funding and launching their businesses...it is a whole cycle. Besides this I am required to monitor and facilitate the progress of our existing clients, organise the CCDP programme, attend networking meetings and widen our service network, work with my other colleagues to organising trainings and promote our client companies in local and international competitions..."

The following quotes show what the IM's felt were key aspects of their role:

[DubInc IM] “...My most useful aspect is my commercial background as manager....working in various organizations in different capacities...this helps me strategising with our clients and coordinating everything..."

[DubInc IM] “...The greatest influence I have on client firms is in the day-to-day stuff that allows them to get on with their business...remove worries..."

[IncuWorks IM] “...My academic background helps build a rapport with our clients, especially spin-ins, because they feel that I can emphatically understand the unpredictable process of commercialising scientific research..."

[IncuWorks IM] "...Helping companies to understand the need to be innovative at all times and not being fixed on only one product or aspect of the business..."

[DubInc IM] “...Would like to spend more time with clients but as you can see I wear a number of different hats..."

While the DubInc IM's tasks fall into both the above categories (corporate and incubation), evidence showed that IncuWorks' IM's role is much more focused on the second category i.e. incubation activities aimed at helping client firms grow. Corporate and administrative responsibilities fell into the Director's domain who was assisted by a variety of specialized staff. Therefore, in judging and planning the incubator management role, it is apparent that balances need to be struck between:

1. Premises management and client support services

2. The provision of day-to-day help and strategic inputs 
3. The focus on the current and potential client firms and focus on local and regional economic development

In the absence of an incubation profession regulatory body (like those that regulate the medical, accounting and actuarial professions) time allocation to the above three categories of 'competing priorities' by IMs is usually a reflection of Board expectations and the IM's 'personal leadership style'. The 'leadership style' aspect seems to have a very strong bearing on client attitudes towards incubation. The IM-Client dyadic relationship is quite closely related to the IM's leadership and management style and impacts whether or not a client decides to work with the IM. To illustrate, a number of clients stated:

[Client 9] "...Contact with the IM has been informal with good access...lots of interaction...(gender ref. removed) is quite approachable and easy-to-talk-to..."

[Client 31] “...Relationships are good...the IM takes an interest in the growth of the firm, introduced us to other clients and has helped us identify customers...this a good benefit..."

[Client 39] “...I sometimes get useful nuggets of information by talking with the management here, but I personally don't know the IM at all..."

[Client 16] "... The relationship between us and the Centre is sticky...I feel they don't consider clients as proper customers...there is a need for a bit more professionalism...I would not treat my customers like the Centre treats its clients..."

[Client 28] “...I have never felt any unease in approaching the IM or other staff here...they are not pushy...we can talk whenever needed...but it is quite rare that I'd approach the IM with a business problem because we have our own network and there is a lot of support from the parent company..."

(Client 4] "...I think it makes a big difference if the IM is emphatic, experienced and has good contact...there is a need to build trust and rapport without which I don't think there will a chance to move forward... here I suppose the IM needs to come across as interested and proactive...otherwise how would we know..."

Based on the client quotes above, and other confidential client firm feedback, dyadic coproduction would be greatly enhanced if the IM displayed emphatic behavior, showed a keenness to devote personal time, had domain (market, sectoral and technical) knowledge and had a dense network of useful and resourceful contacts. If these important ingredients were missing in an IM's leadership style, clients felt that the role of the IM would become irrelevant and it was likely that dyadic co-production would greatly slow down or halt altogether. The importance of these IM leadership attributes became prominent when clients were requested to compare the leadership and management styles of one of the case organization's previous IMs with the recently appointed new IM. In the words of clients:

[Client 19] “...X (previous IM) was I am sure a very nice person but seemed very formal and reserved, was usually in the office with the door closed, we did not really have much contact, perhaps once a week in the corridor when we'd see each other and wave hello or something... but since Y (the new IM) took over, things are very different, (gender ref. removed) comes to my office every week, sends out personalised emails regularly, is very friendly and seems keen...I think age also makes a difference...we are like peers now..."

[Client 14] “...the culture here is entirely different since Y (the new IM) took over, there is much more openness and rapport, it feels more like an incubator now...previously I'd say it was somewhat like a commercial office let..." 
Ultimately, the leadership style of IMs has an important bearing on the range and quantum of dyadic co-production (Ahmad and Ingle 2011). The greater the degrees of perceived empathy, proactivity, domain knowledge and network density, the greater are the chances that clients will engage in developmental co-production. Previous practitioner research has highlighted that there is no clear evidence that the skills and time inputted to face-to-face involvement with clients and the leadership/management style of the IM have direct influence on the development of incubator clients as a whole (UKBI 2001). However, this research has found that there are examples where the amount of time spent with individual clients, and/or where the level and type of intervention is higher, leads to greater benefits being perceived by clients. Clients and graduated firms regard support and encouragement from the IM very highly. Even though the IM's personal involvement may not be a direct cause of improved business performance for all clients, the IM remains significant in terms of the clients feeling recognised and appreciated within the incubator.

\section{Discussion}

In the Literature Review section, it was proposed that given their purpose-an organization designed to grow other organizations-incubators, as hybrid organizations, are much more complex than the conventional firm model put forth by heterodox theories of the firm. However, what was lacking in extant literature were explanations for why incubators were able to effectively maintain and replicate their structures in a wide variety of sociocultural, economic and institutional contexts, delivering value. The research's contribution towards this interesting area comes from two lines of argument which provide valid explanations for why, despite negative evaluations and other methodological issues in establishing the incubator model's true value as a policy instrument for new venture creation, governments around the world continue to invest significant sums of capital in setting up and running business incubators to solve problems related to economic regeneration. These two contributions are highlighted in the sections below:

\subsection{Implications arising out of structural de-coupling}

Like some other hybrid organizations (such as universities and social movement organizations for instance), incubators function with "structural de-coupling"- the idea that the creation and maintenance of gaps between formal policies and actual organizational practices allows certain types of organizations to function. De-coupling has been observed in a variety of organizations, including educational organizations (Meyer and Rowan 1978; Delucchi 2000), corporations (Westphal and Zajac 2001), government agencies (Lines 2005), and social movement organizations (Elsbach and Sutton 1992).

De-coupling occurs in instances where organizational control does not affect all areas of activity equally, and at times structure is disconnected from technical (work) activity, and activity is disconnected from its effects (Meyer and Rowan 1978). In other words, decoupling of structure is the idea that the creation and maintenance of gaps between formal policies and actual organizational practices allows certain types of organizations to function. It is proposed that structural de-coupling is inherent to incubators where the major activity of the incubator organization (incubation) tends to be disconnected from organizational control structures and the activity itself is disconnected from its true impacts. 
There were varying degrees of structural de-coupling observed in the two case organizations, impacted by the IM's task variety and key performance indicators. It is proposed that levels of de-coupling influence a particular leadership style to emerge, thereby, influencing incubation strategy (dormant, proactive or reactive) and incubation approach (coaching or mentoring). In incubators with high levels of de-coupling, the focus of IM activity would be organizational self-preservation and bolstering legitimacy and reputation. This is at a cost of devoting time and resources to the core purpose of the incubatorincubating. Lower levels of de-coupling is likely to have an opposite effect i.e. a greater IM focus on the core organizational activity due to higher levels of accountability, monitoring, tie-in of IM incentives to incubating, clearer definition of the IM's role and the presence of alternate 'resources' to manage the incubator firm or corporation.

De-coupling within incubators serves to bolster legitimacy and reputation. Incubators avoid close inspections because elaborate displays of confidence and trust can increase the commitments of internal participants. By agreeing that IMs have incubation delivery competence, maximum social responsibility for upholding the ethos of incubation goes to the IMs. This enables incubator organizations to gain legitimacy with their external constituents while simultaneously maintaining internal flexibility to address practical considerations. By avoiding close inspections and through elaborate displays of confidence and trust, commitments of internal members increase. By assuming that incubator managers (IM) are competent at incubating, maximum social responsibility for upholding the ethos of incubation becomes the IMs' responsibility. This in turn allows for the maintenance of the incubator's internal structure, and allows for easy replication in a variety of contexts.

\subsection{Mis-alignment of managerial incentives with the actual work of incubating}

The complex and nearly impossible-to-monitor work of the IM raises a number of interesting points, such as, what is truly required of an incubator manager?; and, whether personal leadership style has any impact on incubation ethos, strategy and triggers? It is proposed that the personal leadership style, personality and behavioral traits of the IM have tremendous bearing on the overall quality, levels and intensity of developmental assistance activity at an incubator organization. The effectiveness of leadership styles has long been a topic of discussion in both academic and practitioner circles (Howell and Avolio 1992; Avolio and Bass 1995; Avolio 1999). Most managers exhibit components of several different leadership styles such as transformational behavior, contingent reward leadership and management-by-exception leadership (Bass and Steidlmeier 1999), therefore, it becomes difficult to precisely point-point an individual manager's exhibited style. However, researchers agree that effective leadership in any role requires a manager to be adept at a number of common skills such as being able to develop and coach subordinates, communicate clearly, resolve conflicts, analyze problems, make sound decisions, be able to respond to work challenges in a positive way, use time efficiently, and delegate work (Davis et al. 1996).

It is proposed that building and nurturing an IM-Client relationship is much more difficult than building more conventional familial or professional relationships such as those between a VC-entrepreneur and landlord-tenant. The IM operates in a number of different capacities, at a number of different levels, and as a consequence maintains several different relationships with clients including that of landlord, shareholder, mentor, referee and broker. Depending on the nature of the IM-Client dyadic relationship, the IM must 
wear a number of different 'hats' simultaneously whilst maintaining enough levels of rapport to facilitate dyadic co-production. An upset in any one of these roles can have an impact on the level of rapport, thereby, on the efficacy of dyadic co-production. Thus, the IM's role is by its very nature a complex one, and is primarily about influencing clients by building and maintaining quality relationships.

The one normative advantage the IM has, in balancing anticipated benefits against costs and risks, is the value of the relationship. The incubation relationship is such that, in aggregate, neither of the two parties (IM and Client) is significantly vulnerable without each other, but nonetheless, the relationship provides necessary and sufficient benefits. Therefore, the risk in sharing and imparting knowledge is reduced, since, due to the nature of the relationship, the likelihood of one partner abusing or exploiting the relationship is low as there is no real incentive or gain by abusing the relationship.

This complexity undoubtedly gives rise to heightened uncertainty in the internal managerial environment, and helps in explaining why incubator evaluation and impact assessment cannot be meaningful using traditional evaluation tools. Three aspects that lead to client-level uncertainty, which to the best of knowledge, have not been previously examined: (1) clients not being able to precisely pin-point the areas where they needed incubator intervention; (2) clients uncertain about what developmental assistance, coaching and mentoring actually meant in practice; and (3) clients uncertain about whether they should or could approach the IM for assistance and advice.

\section{Conclusion}

The aim in this paper was to contribute new explanatory theory that drew attention to incubators' structural properties, which facilitate its replication and performance in a range of contexts. The two contributions inducted via the analysis of case data and by drawing on the literature on hybrid organizations, highlighted the reasons why incubators' internal structure remains robust, withstanding all forms of scrutiny and criticism, to replicate, and rapidly spread across the globe, becoming a favorite public policy mechanism for economic regeneration and job creation. An interesting question at this juncture would be: how did this occur so rapidly and effectively?

It is widely known that business incubators were setup as responses to prevailing environmental conditions. The originators of the incubator-model interpreted their internal and external environments to conceive an innovation that reflected genuine problems. The incubator's structure was adopted to complement both agent strategy and external environmental transformations. Initially, the most powerful actors who supported new incubator setup were states and universities in the US. The support received also awarded political legitimacy to the nascent incubator-form. Thus, the award of political legitimacy was a two-way process. An increase in the incubator-form's political legitimacy led to further diffusion since legitimated structures are quickly transmitted in a field through tradition, represented by the field's founding organizations; through imitation, based on the field's currently most prevalent forms; through coercion, exercised by the field's dominant organizations; and through normative pressures, diffused through educational organizations and social networks. An innovation is institutionalized when no question arises in the minds of actors that a certain form is the natural way to affect some kind of collective action. In the case of incubators, precisely because it has been difficult to evaluate their outcomes and contributions and to link these to programmatic objectives and budgets and 
that they serve the political interests of the proponents of the prevalent paradigm of economic development, despite negative evaluations, they remain institutionalized as essential components of the US national technology policy and innovation system.

Finally, much of the modern incubation literature, however, posits a diverse and differentiated world of incubator models and seeks to explain variation in their structure and behaviour. To this, institutional theorists would argue, that although in the initial stages of their life cycle, organizational fields do display considerable diversity in approach and form, but once a field becomes well established there is an inexorable push towards homogenization. Once disparate organizations in the same line of business are structured into an actual field (by competition, the state, or the professions), powerful forces emerge that lead them to become more similar to one another. Organizations may change their goals or develop new practices, and new organizations enter the field. In the long run though, organizational actors construct around themselves an environment that constrains their ability to change further in later years.

Open Access This article is distributed under the terms of the Creative Commons Attribution 4.0 International License (http://creativecommons.org/licenses/by/4.0/), which permits unrestricted use, distribution, and reproduction in any medium, provided you give appropriate credit to the original author(s) and the source, provide a link to the Creative Commons license, and indicate if changes were made.

\section{References}

Aaboen, L. (2009). Explaining incubators using firm analogy. Technovation, 29(10), 657-670.

Adkins, D. (2002). A brief history of business incubation in the United States. Athens, OH: NBIA.

Adler, P. S., \& Kwon, S. (2002). Social capital: Prospects for a new concept. Academy of Management Review, 27, 17-40.

Aernoudt, R. (2004). Incubators: Tool for entrepreneurship? Small Business Economics, 23, 127-135.

Ahmad, A. J. (2014). A mechanisms-driven theory of business incubation. International Journal of Entrepreneurial Behaviour \& Research, 20(4), 375-405.

Ahmad, A. J., \& Ingle, S. (2011). Relationships matter: Case study of a university campus incubator. International Journal of Entrepreneurial Behaviour \& Research, 17(6), 626-644.

Allen, D. N., \& McCluskey, R. (1990). Structure, policy, services, and performance in the business incubator industry. Entrepreneurship Theory and Practice, 15(2), 61-77.

Avolio, B. J. (1999). Full leadership development. Beverly Hills, California: Sage Publications.

Avolio, B. J., \& Bass, B. M. (1995). Individual consideration viewed at multiple levels of analysis: A multiframework for examining the diffusion of transformational leadership. Leadership Quarterly, 6, $188-218$.

Barney, J. B., \& Hesterly, W. (2006). Organizational economics: Understanding the relationship between organizations and economic analysis. In S. R. Clegg, C. Hardy, T. B. Lawrence, \& W. R. Nord (Eds.), The Sage handbook of organization studies. London: Sage Publications.

Barretta, A. (2008). The functioning of co-opetition in the health-care sector: An explorative analysis. Scandinavian Journal of Management, 24, 209-220.

Bass, B. M., \& Steidlmeier, P. (1999). Ethics, character, and authentic transformational leadership behaviour. Leadership Quarterly, 10(2), 181-217.

Battilana, J., Sngul, M., Pache, A., \& Model, J. (2015). Harnessing productive tensions in hybrid organizations: The case of work integration social enterprises. Academy of Management Journal, 58(6), $1658-1858$.

Bercovitz, J., \& Feldman, M. (2007). Fishing upstream: Firm innovation strategy and university research alliances. Research Policy, 36, 930-948.

Bergek, A., \& Norrman, C. (2008). Incubator best practice: A framework. Technovation, 28(1-2), 20-28.

Bøllingtoft, A., \& Ulhøi, J. P. (2005). The networked business incubator-leveraging entrepreneurial agency? Journal of Business Venturing, 20(2), 265-290.

Borys, B., \& Jemison, D. (1989). Hybrid arrangements as strategic alliances: Theoretical issues in organizational combinations? Academy of Management Review, 14(2), 234-249. 
Boyd, K. (2006). Developing a business incubation program. In M. Erlewine (Ed.), Athens, OH: NBIA Publications.

Bruneel, J., Ratinho, T., Clarysse, B., et al. (2012). The evolution of business incubators: Comparing demand and supply of business incubation services across different incubator generations. Technovation, 32, 110-121.

Byrne, O. (2005). Enterprise Ireland-Campus business incubation best practice manual.

Capaldo, A., \& Petruzzelli, A. (2011). In search of alliance-level relational capabilities: Balancing innovation value creation and appropriability in R\&D alliances. Scandinavian Journal of Management, 27, 273-286.

Clarysse, B., Wright, M., Lockett, A., Van de Velde, E., \& Vohora, A. (2005). Spinning out new ventures: A typology of incubation strategies from European research institutions. Journal of Business Venturing, 20(2), 183-216.

Cohen, S. (2013). What do accelerators do? Insights from incubators and angels. Innovations, 8(3-4), 19-25.

Cooper, S. Y., \& Park, J. S. (2008). The impact of 'Incubator' organizations on opportunity recognition and technology innovation in new, entrepreneurial high-technology ventures. International Small Business Journal, 26(1), 27-56.

Dacin, M. T., Goodstein, J., \& Scott, W. R. (2002). Institutional theory and institutional change: Introduction to the special research forum. Academy of Management Journal, 45(1), 45-56.

Davis, B. L., Skube, C. J., Hellervik, L. W., Gebelein, S. H., \& Sheard, J. L. (1996). Successful manager's handbook: Development suggestions for today's managers. Minneapolis, MN: Personnel Decisions Inc.

Delucchi, M. (2000). Staking a claim: The decoupling of liberal arts mission statements from baccalaureate degrees awarded in higher education. Sociological Inquiry, 70, 157-171.

Eisenhardt, K. M., \& Graebner, M. E. (2007). Theory building from cases: Opportunities and challenges. Academy of Management Journal, 50(1), 25-32.

Elsbach, K. D., \& Sutton, R. (1992). Acquiring organizational legitimacy through illegitimate actions: A marriage of institutional and impression management theories. Academy of Management Journal, 35, 699-738.

Entrepreneurship in Ireland. (2014). National policy statement on entrepreneurship in Ireland. Government of Ireland. https://www.localenterprise.ie/Documents-and-Publications/Entrepreneurship-in-Ireland2014.pdf. Accessed November 15, 2016.

French, W. L., Kast, F. E., \& Rosenzweig, J. E. (1985). Understanding human behavior in organizations. New York: Harper \& Row.

Grimaldi, R., \& Grandi, A. (2005). Business incubators and new venture creation: An assessment of incubating models. Technovation, 25(2), 111-121.

Hackett, S. M., \& Dilts, D. M. (2004a). A systematic review of business incubation research. Journal of Technology Transfer, 29(1), 55.

Hackett, S. M., \& Dilts, D. M. (2004b). A real options-driven theory of business incubation. Journal of Technology Transfer, 29, 41-54.

Hoffmann, W. (2007). Strategies for managing a portfolio of alliances. Strategic Management Journal, 28, $827-856$.

Howell, J., \& Avolio, B. J. (1992). The ethics of charismatic leadership: Submission or liberation? The Academy of Management Executive., 6(2), 43-54.

Hughes, M., Ireland, R. D., \& Morgan, R. E. (2007). Stimulating dynamic value: Social capital and business incubation as a pathway to competitive success. Long Range Planning, 40(2), 154.

Jolink, A., \& Niesten, E. (2012). Recent qualitative advances on hybrid organizations: Taking stock, looking ahead. Scandinavian Journal of Management, 28(2), 149-161.

Khalid, F. A., Gilbert, D., \& Huq, A. (2014). The way forward for business incubation process in ICT incubators in Malaysia. International Journal of Business and Society, 15(3), 395-412.

Lewis, D. A. (2002). Does technology incubation work? A critical review of evidence. Athens, OH: National Business Incubation Association.

Lines, K. (2005). MIS and the problem of decoupling in e-government reforms. Scandinavian Journal of Information Systems, 17(2), 107-132.

Lyon, F. (2006). Managing co-operation: Trust and power in Ghanaian associations. Organization Studies, 27(1), 31-52.

Mas-Verdú, F., Ribeiro-Soriano, D., \& Roig-Tierno, N. (2015). Firm survival: The role of incubators and business characteristics. Journal of Business Research, 68(4), 793-796.

Ménard, C. (2004). The economics of hybrid organizations. Journal of Institutional and Theoretical Economics, 160(3), 345-376. 
Ménard, C. (2010). Hybrid modes of organization: Alliances, joint ventures, networks and other 'strange' animals. Working paper (number: halshs00624291). In R. Gibbons \& J. Roberts (Eds.), Handbook of organizational economics. Princeton: Princeton University Press.

Meyer, J. W., \& Rowan, B. (1977). Institutionalized organizations: Formal structure as myth and ceremony. The American Journal of Sociology, 83(2), 340-363.

Meyer, J. W., \& Rowan, B. (1978). The structure of educational organizations. In J. W. Meyer (Ed.), Environments and organizations (pp. 78-109). San Francisco: Jossey-Bass.

Mian, S. A. (1997). Assessing and managing the university technology business incubator: An integrative framework. Journal of Business Venturing, 12(4), 251-340.

Miles, M. B., \& Huberman, A. M. (1984). Qualitative data analysis: An expanded sourcebook. Thousand Oakes, CA: Sage.

NBIA. (2008). Principles and best practices of successful business incubation. http://www.nbia.org/ resource_center/best_practices/index.php. Accessed May 19, 2014.

Ndabeni, L. L. (2008). The contribution of business incubators and technology stations to small enterprise development in South Africa. Development Southern Africa., 25(3), 259-268.

Ozcan, P., \& Eisenhardt, K. (2009). Origin of alliance portfolios: Entrepreneurs, network strategies, and firm performance. Academy of Management Journal, 52(2), 246-279.

Patton, M. Q. (1990). Qualitative research and evaluation methods (3rd ed.). Newbury Park, CA: Sage.

Phan, P. H., Siegel, D. S., \& Wright, M. (2005). Science parks and incubators: Observations, synthesis and future research. Journal of Business Venturing, 20, 165-182.

Raynaud, E., Sauvée, L., \& Valceschini, E. (2009). Aligning branding strategies and governance of vertical transactions in agri-food chains. Industrial and Corporate Change, 18(5), 835-868.

Robinson, S., \& Stubberud, H. A. (2014). Business Incubators: What services do business owners really use? International Journal of Entrepreneurship, 18, 29-39.

Rosenberg, J. P., \& Yates, P. M. (2007). Schematic representation of case study research designs. Journal of Advanced Nursing, 60(4), 447-452.

Rubin, T. H., Aas, T. H., \& Stead, A. (2015). Knowledge flow in technological business incubators: Evidence from Australia and Israel. Technovation, 41-42, 11-24.

Rudy, A. (2004). Incubators: Tool for Entrepreneurship? Small Business Economics, 23(2), 127-135.

Sá, C., \& Lee, H. (2012). Science, business, and innovation: Understanding networks in technology-based incubators. $R \& D$ Management, 42(3), 243-253.

Sanders, J. (2014). Entrepreneurship development through business incubators \& accelerators in times of transition: The case of Egypt. Robert H. Smith School Research Paper No. RHS 2490716. http://ssrn. com/abstract=2490716.

Schwartz, M., \& Hornych, C. (2010). Cooperation patterns of incubator firms and the impact of incubator specialization: Emperical evidence from Germany. Technovation, 30, 485-495.

Scillitoe, J. L., \& Chakrabarti, A. K. (2010). The role of incubator interactions in assisting new ventures. Technovation, 30, 155-167.

Sherman, H. (1999). Assessing the intervention effectiveness of business incubation programs on new business start-ups. Journal of Developmental Entrepreneurship, 4(2), 117-133.

Sofouli, E., \& Vonortas, N. S. (2007). S\&T Parks and business incubators in middle-sized countries: The case of Greece. Journal of Technology Transfer, 32(5), 525-545.

SUMMIT-II. (2010). Business incubator management training institute. http://www.summitii.org.

Sun, H., Ni, W., \& Leung, J. (2007). Critical success factors for technological incubation: Case study of hong kong science and technology parks. International Journal of Management, 24(2), 346-363.

Tamásy, C. (2007). Rethinking technology-oriented business incubators: Developing a robust policy instrument for entrepreneurship, innovation, and regional development? Growth and Change, 38(3), 460 .

Todorovic, Z. W., \& Moenter, K. M. (2010). Tenant firm progression within an incubator: Progression toward an optimal point of resource utilization. Academy of Entrepreneurship Journal, 16(1), 23.

UKBI. (2001). Incubators: Identifying best practice. UK Business Incubation Limited, Birmingham, United Kingdom. www.ukbi.org.uk.

UKBI. (2006). Bench marking survey. UK Business Incubation Limited, Birmingham, United Kingdom. www.ukbi.org.uk.

Ulset, S. (2008). The rise and fall of global network alliances. Industrial and Corporate Change, 17(2), 267-300.

Vanderstraeten, J., \& Matthyssens, P. (2012). Service-based differentiations strategies for business incubators: Exploring external and internal alignment. Technovation, 32, 656-670.

Westphal, J. D., \& Zajac, E. (2001). Explaining institutional decoupling: The case of stock repurchase programs. Administrative Science Quarterly, 46, 202-228. 
Woolthuis, R. K., Hillebrand, B., \& Nooteboom, B. (2005). Trust, contract and relationship development. Organization Studies, 26(6), 813-840.

Yin, R. K. (2009). Case study research: Design and methods (4th ed.). Beverly Hills, California: SAGE Publications.

Yvrande-Billon, A., \& Ménard, C. (2005). Institutional constraints and organizational changes: The case of the British rail reform. Journal of Economic Behavior \& Organization, 56, 675-699.

Zhang, H., Wenqing, W., \& Zhao, L. (2016). A study of knowledge supernetworks and network robustness in different business incubators. Physica A, 447, 545-560. 